Kocaeli Journal of Science and Engineering

\title{
Spatial Regression Models for Explaining AQI Values in Cities of Turkey
}

\author{
Fusun YALCIN ${ }^{1, *}$ (D), Ahmet Mustafa TEPE ${ }^{2}$ (D), Güray DOĞAN ${ }^{3}$ (D), Nurfer CIZMECI ${ }^{4}$ (D) \\ ${ }^{1}$ Akdeniz University, Department of Mathematics, Antalya, 07058, Turkey, ORCID: 0000-0002-2669-1044 \\ ${ }^{2}$ Akdeniz University, Department of Environment Sciences, Antalya, 07058, Turkey, ORCID: 0000-0002-5210-6291 \\ ${ }^{3}$ Akdeniz University, Department of Environment Sciences, Antalya, 07058, Turkey, ORCID: 0000-0003-0481-8080 \\ ${ }^{4}$ Ministry of Education, Antalya, 07058, Turkey, ORCID: 0000-0002-5275-6120
}

\section{Article Info}

Research paper

Received : October 01, 2020

Accepted : December 01, 2020

\begin{abstract}
The aim of this study is to determine the natural and anthropogenic factors affecting the air quality index (AQI) and to create a model that shows the effects of these factors on AQI values in cities of Turkey. Natural and anthropogenic factors, which are thought to have an effect on AQI, were determined and interpreted with kriging maps. The effects of these factors on AQI were examined by explanatory spatial data analysis (ESDA). Global Moran's I and local Moran's I (LISA) indices were examined for the presence of spatial relation. Spatial lag model (SLM) was proposed for parameter estimation instead of ordinary least squares method (OLS) and the average AQI values for 2014 and 2015 were compared. It was also concluded that the average AQI values of 2014 and 2015 were in a strong correlation relationship (Pearson correlation coefficient of 0.914). On the Southern Anatolia, desert dust transport decreases the air quality of the region, however on the Black Sea coast, meteorological factors have a strong effect on air quality. Both SLM and OLS models showed that higher wind speed increases air quality in the cities while increase in GDP increases AQI.
\end{abstract}

Keywords

Exploratory Spatial Data Analysis

(ESDA)

Air Quality Index (AQI)

Spatial Regression Models

Moran's I

Local Indicators of Spatial

Association (LISA)

\section{Introduction}

Low air quality has a negative effect on human health, vegetation, structures, ecosystem, and climate. Worldwide, 3.8 million premature deaths annually are attributed to ambient air pollution. Average particulate air pollution levels in many developing cities can be 4-15 times higher than World Health Organization (WHO) air quality guideline levels [1]. Ozone, which is formed as a result of the reaction of volatile organic compounds and nitrous oxides through sun rays in the troposphere, has a negative effect on human health and harms agricultural products and ecosystems [2-4]. Sulfur dioxide, another important anthropogenic pollutant, is released as a result of the burning of fossil fuels containing sulfur and causes acid

* Corresponding Author: fusunyalcin@akdeniz.edu.tr rains to occur in case of long-distance transport [5].

The air quality index (AQI) was developed to evaluate all atmospheric pollutants together in the urban environment and to easily share air quality with people. AQI, which was developed primarily in the USA, was used similarly in almost all of the world. AQI is generally calculated for particulate matter, carbon monoxide (CO), Sulfur dioxide $\left(\mathrm{SO}_{2}\right)$, Nitrogen dioxide (NO2) and Ozone $\left(\mathrm{O}_{3}\right)[6]$.

There are lots of studies carried out on the parameters affecting the air quality in the urban atmosphere in various parts of the worlds [7-11] and in Turkey [12-20]. These studies generally focused on the effects of urban pollution sources. However, the effects of regional processes and regional sources on AQI were not emphasized. Therefore, in those studies, regional drivers of urban air pollution are underestimated. In order to understand the spatial dependence in air quality, Local indicators of spatial association (LISA) analysis can be used. This analysis, 
which assumes a spatial dependence, has been used in many areas where the local impact is considered in recent years [21-24].

In this study, it is aimed to identify the important parameters that have a negative and positive impact on air quality of urban atmospheres of Turkey for the year 2015. With the use of the results of the analysis, regional associations and differences in AQI were also investigated. In addition, the results of this research were helpful for the identification of the regionally effective parameters on AQI. These data for 2015 are compared with the data for 2014 that have been previously published [25]. The MATLAB, ArcGIS 10.2 and GeoDA programs were used to create the exploratory spatial data analysis (ESDA), global Moran's I and local Moran's I index calculation, ordinary least squares (OLS), spatial lag model (SLM) and spatial error model (SEM), which we use to estimate the spatial distribution of the air quality index and the factors affecting it.

\section{Materials and Methods}

\subsection{Study Area}

Turkey is located on Easteran Mediterranean basin. Turkey is the 37th largest country, with a total area of about $783600 \mathrm{~km} 2$ however, it is the 17th most populous country with a population of approximately 84 million. There are 81 cities in Turkey and 23 of these have populations above one million. The rainfall and temperature pattern of Turkey is controlled by four pressure centres located over Basra, Azor, Siberia and Iceland. In summer, meteorology of Turkey is under influence of Basra low pressure centre and Azor high pressure centre. However in winter, Siberia high pressure center and Iceland low pressure centers, which cause colder climatic conditions and more precipiation, respectively, are more effective in Turkey. The climatic conditions differ significantly due to existence of the mountains that run parallel to the coasts. The coastal regions areas have a milder climate and the inner plateau of Anatolia has hot summers and cold winters with limited rainfall [26].

\subsection{Data}

Air quality index values of the year 2015 were calculated from data obtained from air quality monitoring stations operated by Ministry of Environment and Urbanization. The AQI data for 2014 were taken from the previous study [25],[27]). The General Directorate of Meteorology provided daily, temperature, precipitation, wind speed and direction, relative humidity, atmospheric pressure, sunshine duration, mixture height, intraday temperature change and cloudiness data. Then, some of these data were re-arranged as "annual average" and others as "annual total". Vehicle density, altitude, urban population, total population, population density, urbanization, per capita national income data were obtained from Turkey statistical institute (TSI). Descriptions of these data are given in Table 1.

Table 1. Descriptions of variables.

\begin{tabular}{|c|c|c|}
\hline $\begin{array}{l}\text { Independent } \\
\text { variables }\end{array}$ & Unit & $\begin{array}{l}\text { Brief descriptions of the } \\
\text { variables }\end{array}$ \\
\hline AQI & & Air Quality Index \\
\hline Wind Speed & $\mathrm{m} / \mathrm{s}$ & $\begin{array}{l}\text { Annual Average Wind } \\
\text { Speed of Cities }\end{array}$ \\
\hline $\begin{array}{ll}\text { Average } & \text { Actual } \\
\text { Pressure } & \\
\end{array}$ & $\mathrm{kPa}$ & $\begin{array}{l}\text { Annual Average Pressure } \\
\text { of Cities }\end{array}$ \\
\hline $\begin{array}{l}\text { Average } \\
\text { Humidity }\end{array}$ & & $\begin{array}{l}\text { Annual Average Humidity } \\
\text { of Cities }\end{array}$ \\
\hline $\begin{array}{l}\text { Google } \\
\text { Altitude(M) }\end{array}$ & $\mathrm{m}$ & $\begin{array}{l}\text { Cities' Altitudes Above Sea } \\
\text { Level }\end{array}$ \\
\hline $\begin{array}{l}\text { Average Sunshine } \\
\text { Duration }\end{array}$ & hour & $\begin{array}{l}\text { Annual Average } \\
\text { Sunbathing of Cities }\end{array}$ \\
\hline $\begin{array}{l}\text { Total } \\
\text { Precipitation }\end{array}$ & $\mathrm{mm}$ & $\begin{array}{l}\text { Annual Average Rainfall } \\
\text { of Cities }\end{array}$ \\
\hline $\begin{array}{l}\text { Average } \\
\text { Temperature }\end{array}$ & OC & $\begin{array}{l}\text { Annual Average } \\
\text { Temperature of Cities }\end{array}$ \\
\hline $\begin{array}{lr}\text { Number } & \text { of } \\
\text { Automobiles } & \text { Per } \\
\text { Capita } & \\
\end{array}$ & car/person & $\begin{array}{l}\text { Number of Cars Per Year } \\
\text { Per Person in Cities }\end{array}$ \\
\hline $\begin{array}{l}\text { Number of } \\
\text { People Per Car }\end{array}$ & person/car & $\begin{array}{l}\text { Number of Cities Per } \\
\text { Annual Car }\end{array}$ \\
\hline Secon-Ind & TL & $\begin{array}{l}\text { Gross Domestic Product by } \\
\text { City (for industry) Branch } \\
\text { of Economic Activity }\end{array}$ \\
\hline GDP & $\mathrm{TL}$ & $\begin{array}{l}\text { Gross National Product by } \\
\text { City }\end{array}$ \\
\hline Per capita GDP & TL & $\begin{array}{l}\text { Gross Domestic Product } \\
\text { per Capita by Province }\end{array}$ \\
\hline $\begin{array}{l}\text { Number } \\
\text { Vehicles }\end{array}$ & & $\begin{array}{l}\text { Annual Total Number of } \\
\text { Vehicles in Cities }\end{array}$ \\
\hline Total Population & & $\begin{array}{l}\text { Annual Total Population of } \\
\text { Cities }\end{array}$ \\
\hline $\begin{array}{l}\text { Population } \\
\text { Density }\end{array}$ & $/ \mathrm{km} 2$ & $\begin{array}{l}\text { Annual Population Density } \\
\text { of Cities }\end{array}$ \\
\hline Urbanization Rate & $\%$ & $\begin{array}{l}\text { Urban population / Total } \\
\text { population }\end{array}$ \\
\hline
\end{tabular}

Data such as "gross annual product per capita", gross domestic product (GDP-S) for industry according to the economic activity branches on a provincial basis, gross domestic product per capita (GDP-K) and GDP-B for second level classification of statistical regional units, which are considered to have an impact on air quality, have been obtained from TSI.

Using the "Ordinary kriging spherical model", annual average humidity (Figure 1(a)), annual average pressure (Figure 1(b)), annual total precipitation (Figure 1(c)), annual average temperature (Figure 1(d)), and total population maps (Figure 1(e)) were prepared. 

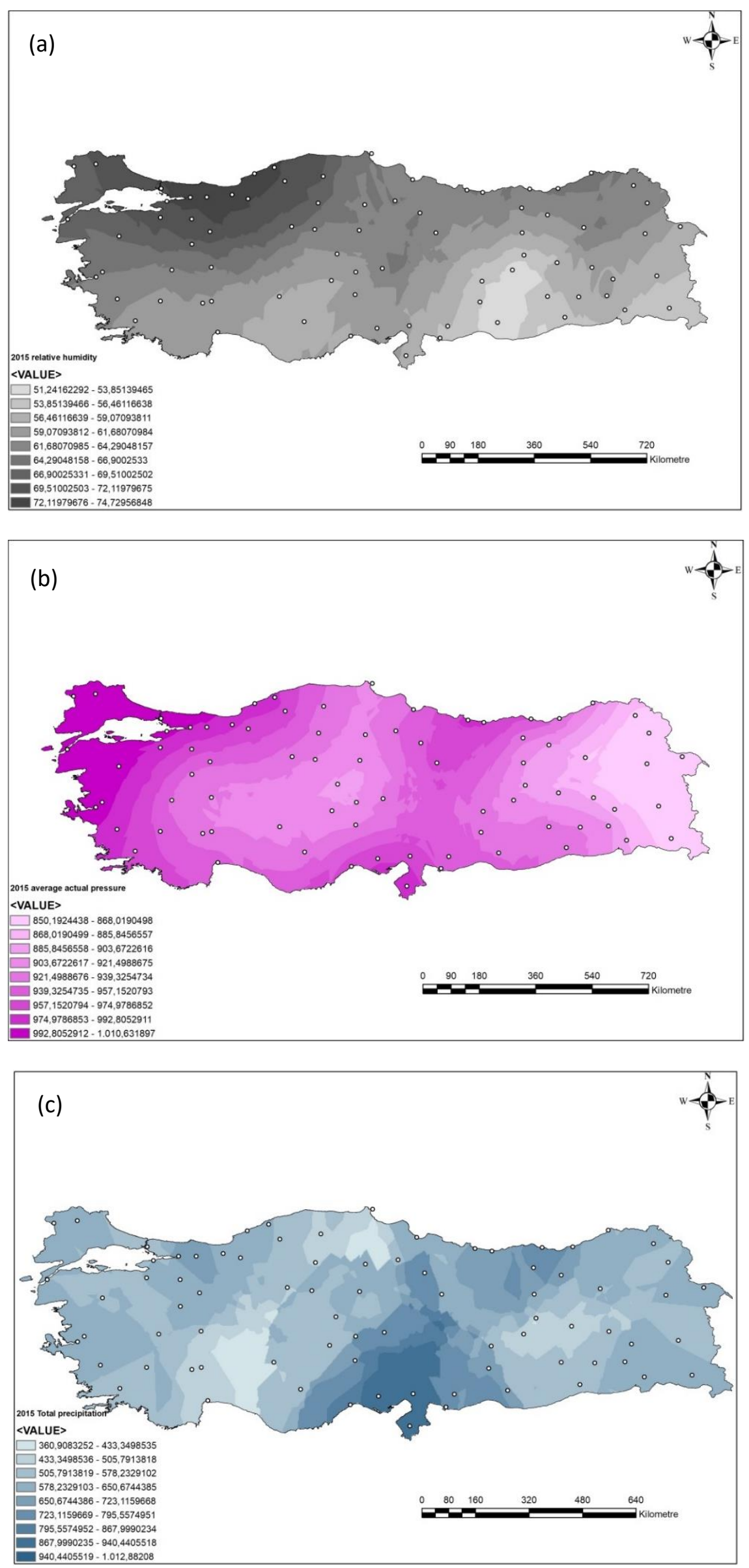

Figure 1. Location map and krigging maps. 

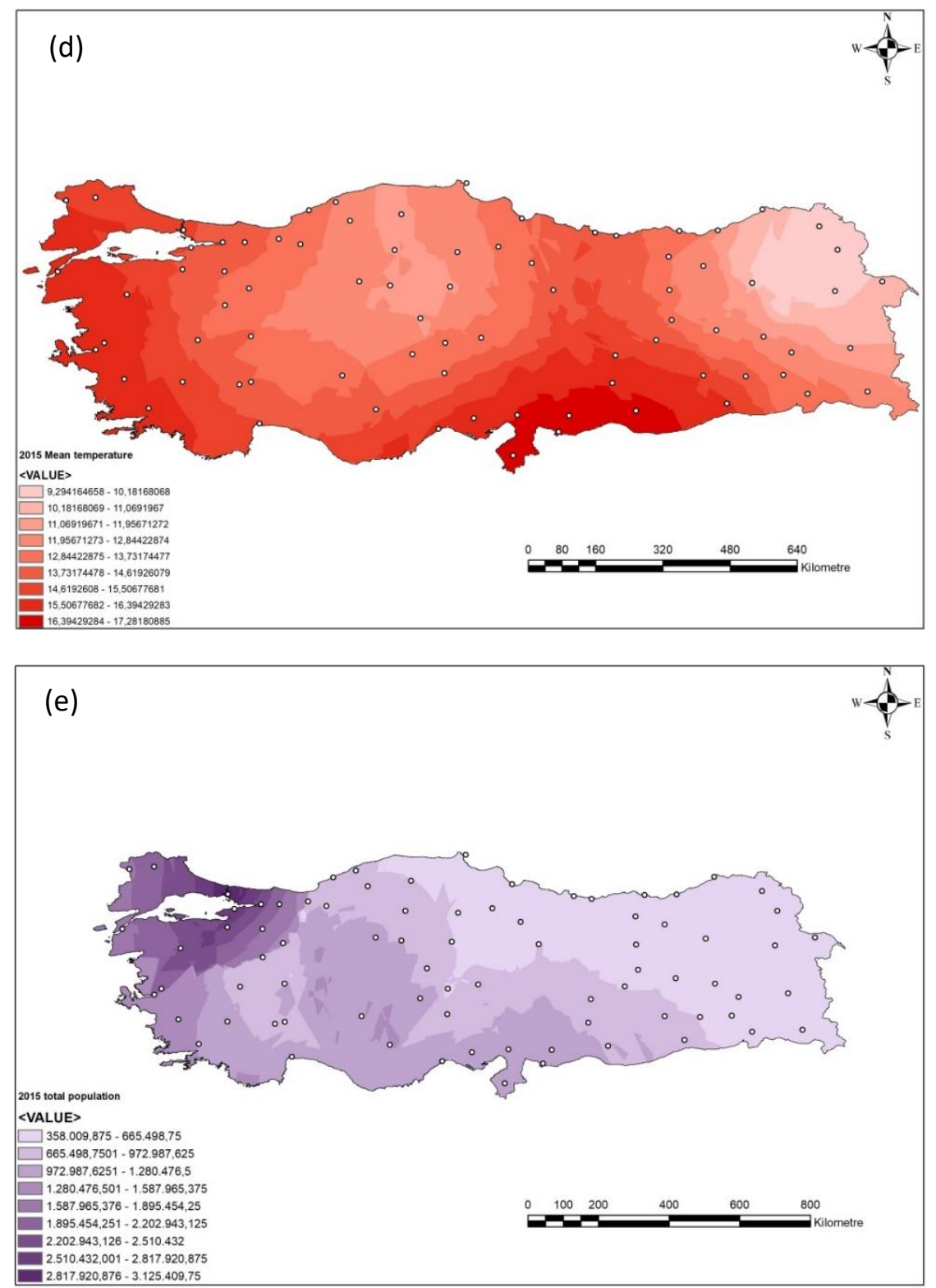

Figure 1. (Cont.) Location map and krigging maps.

Descriptive statistics of variables for spatial models are given in Table 2. In 2015, the lowest AQI value was calculated in Eskişehir with 64, the highest AQI value was 608 and was calculated in Bolu. Incomplete data in the average sunshine duration and total precipitation were completed with the series mean method. Variation Inflation Factor (VIF) related to linear multiple connection problem was investigated. Accordingly, variables with VIF $>10$ are not included in the model.

\subsection{Air Quality Index Calculation}

The air quality data used in this study were obtained from air quality monitoring stations operated by the Ministry of Environment and Civilization of Turkey [28]. There was at least one air quality monitoring station in every city that measures at least $\mathrm{PM}_{10}$ and $\mathrm{SO}_{2}$. If there were more than one monitoring station for a city, then the one that represents the urban background in the downtown area was selected and used in this study.

The data coverage was from January 2014 to December 2015. Before the use of the data, a quality control check was done based on the correlation of data with each other and extraordinary results were excluded from the data set. The AQI is an index for reporting daily air quality and its health effects by converting the observed concentrations to a number on a range of 0 to 500 . An AQI level lower than 50 means that pollutants will not have any significant effect to anyone. If the AQI levels are at or higher 51 , the air quality level defined as moderate, while values below 50 considered satisfactory. Table 3 shows the categories of $\mathrm{AQI}$, the range of pollutant concentrations 
and index values for each category.

The AQI values represent the maximum air quality sub-index of the following pollutants: $\mathrm{PM}_{10}, \mathrm{O}_{3}, \mathrm{SO}_{2}, \mathrm{NO}_{2}$, and CO. AQI is calculated, according to the Turkish standard, by using the pollutant concentration data from Eq. (1):

$I_{p}=\frac{I_{H i}-I_{L o}}{B P_{H i}-B P_{L o}}\left(C_{p}-B P_{L o}\right)+I_{L o}$

where $I_{p}$ is the air quality index for pollutant $p, C_{p}$ is the monitored concentration of pollutant $p, I_{H i}$ is the maximum air quality index value for color category that corresponds to $C_{p}, I_{L o}$ is the minimum air quality index value for color category that corresponds to $C_{p}, B P_{H i}$ is the maximum concentration of air quality index color category that contains $C_{p}, B P_{L o}$ is the minimum concentration of air quality index color category that contains $C_{p}$. Final AQI of a city is determined as the maximum $I_{p}$ value for a given time. In almost all cases, AQI calculated for $\mathrm{PM}_{10}$ was the maximum value. Therefore, daily AQI values of the cities were calculated for the years 2014 and 2015 and those AQI values were used for further analysis. There are 81 provinces in Turkey and except for Bolu, daily AQI was calculated for each province for the years 2014 and 2015. For Bolu, daily AQI values calculated using daily average values of $\mathrm{SO}_{2}$ values because $\mathrm{PM}_{10}$ data of Bolu was not available. Finally, the data was transformed into spatial data by adding the coordinates of the cities to which they belong.

Table 2. Descriptive statistics of the dependent and explanatory variables for 2015 years.

\begin{tabular}{|c|c|c|c|c|c|c|c|}
\hline & $\mathrm{N}$ & & Mean & Std. Deviation & Variance & Min. & Max. \\
\hline & Valid & Missing & & & & & \\
\hline AQI & 81 & 0 & 175.447 & 95.828 & 9183.022 & 64 & 608.96 \\
\hline Wind Speed & 81 & 0 & 1.777 & 0.676 & 0.457 & 0.6 & 3.786 \\
\hline Average Actual Pressure & 81 & 0 & 938.401 & 60.874 & 3705.654 & 819.199 & 1017.386 \\
\hline Average Humidity & 81 & 0 & 62.634 & 9.312 & 86.708 & 43.088 & 87.86 \\
\hline Google Altitude(M) & 81 & 0 & 691.469 & 554.694 & 307684.927 & 4 & 1923 \\
\hline Average Sunshine Duration & 64 & 17 & 6.204 & 1.286 & 1.654 & 1.596 & 8.378 \\
\hline Total Precipitation & 76 & 5 & 673.499 & 401.505 & 161206.232 & 110.7 & 2390 \\
\hline Average Temperature & 81 & 0 & 13.933 & 3.199 & 10.236 & 4.989 & 19.98 \\
\hline $\begin{array}{l}\text { Number of Automobiles Per } \\
\text { Capita }\end{array}$ & 81 & 0 & 0.11 & 0.052 & 0.003 & 0.007 & 0.232 \\
\hline Number of People Per Car & 81 & 0 & 16.455 & 22.437 & 503.431 & 4.311 & 136.654 \\
\hline Secon-Ind & 81 & 0 & 24.374 & 9.350 & 87.416 & 8.17 & 50.458 \\
\hline GDP & 81 & 0 & 28872191.272 & 84018762.234 & 7059152407365370 & 1428560 & 722567040 \\
\hline Percapita GDP & 81 & 0 & 22668.494 & 7741.654 & 59933202.453 & 9657 & 49773 \\
\hline Number of Vehicles & 81 & 0 & 246845.333 & 466433.285 & 217560009188.4 & 7851 & 3624403 \\
\hline Total Population & 81 & 0 & 972111.765 & 1766432 & 3120282010079.6 & 78550 & 14657434 \\
\hline Population Density & 81 & 0 & 124.682 & 314.226 & 98738.216 & 11.582 & 2820.907 \\
\hline Urbanization Rate & 81 & 0 & 0.012 & 0.022 & 0.001 & 0.001 & 0.186 \\
\hline
\end{tabular}


Table 3. Pollutant concentrations for each AQI category of according to Turkish-AQI [28].

\begin{tabular}{|l|l|l|l|l|l|l|}
\hline Index Values & Category & $\begin{array}{l}\mathrm{SO}_{2}(1-\mathrm{hr}) \\
\left(\mu \mathrm{g} / \mathrm{m}^{3}\right)\end{array}$ & $\begin{array}{l}\mathrm{NO}_{2}(1-\mathrm{hr}) \\
\left(\mu \mathrm{g} / \mathrm{m}^{3}\right)\end{array}$ & $\begin{array}{l}\mathrm{CO}(8-\mathrm{hr}) \\
\left(\mathrm{mg} / \mathrm{m}^{3}\right)\end{array}$ & $\begin{array}{l}\mathrm{O}_{3} \quad(8-\mathrm{hr}) \\
(\mu \mathrm{g} / \mathrm{m} 3)\end{array}$ & $\begin{array}{l}\mathrm{PM}_{10}(24-\mathrm{hr}) \\
\left(\mu \mathrm{g} / \mathrm{m}^{3}\right)\end{array}$ \\
\hline $0-50$ & Good & $0-100$ & $0-100$ & $0-5.5$ & $0-120$ & $0-50$ \\
\hline $51-100$ & Moderate & $101-250$ & $101-200$ & $5.5-10$ & $121-160$ & $51-100$ \\
\hline $101-150$ & $\begin{array}{l}\text { Unhealthy } \\
\text { for sensitive } \\
\text { groups }\end{array}$ & $251-500$ & $201-500$ & $10-16$ & $161-180$ & $101-260$ \\
\hline $151-200$ & Unhealthy & $501-850$ & $501-1000$ & $16-24$ & $181-240$ & $261-400$ \\
\hline $201-300$ & $\begin{array}{l}\text { Very } \\
\text { unhealthy }\end{array}$ & $851-1100$ & $1001-2000$ & $24-32$ & $241-700$ & $401-520$ \\
\hline $300-500$ & Severe & $>1101$ & $>2001$ & $>32$ & $>701$ & $>521$ \\
\hline
\end{tabular}

\subsection{Exploratory Spatial Data Analysis (ESDA)}

Exploratory spatial data analysis (ESDA) is frequently used in many fields of basic and social sciences. The first studies were generally on biology and ecology, but especially the map studies by Jhon Snow on a cholera epidemic in London in 1854 contributed to this method [29]. ESDA studies on air quality have been widely seen in the literature in recent years [10], [30-33]. The phrase "everything is related to everything else, but close things are more related to distant things", known as Waldo Tobler's basic law of geography, is known as the leading sentence for spatial studies [34]. Based on this idea, we wanted to examine whether the AQI index values are affected by neighboring cities. The concept of spatial dependence is similar to the autocorrelation that was encountered in time series [35]. Therefore, spatial dependence can be called spatial autocorrelation. Spatial autocorrelation can offer versatile dependence, unlike the one-way dependency in time series. Spatial dependence shows the degree of spatial relationship between similar units in a geographical region and error terms [36]. In this context, there are different indices that measure spatial dependence. The most frequently used ones can be listed as "Moran's I", "Geary's C" and "General G" [37-41], [10]. Spatial autocorrelation can be examined in two ways, local and global. Local spatial autocorrelation (Local Indicators of Spatial Association-LISA) has been defined to determine the "relationship between close neighbors". Global spatial autocorrelation is defined to determine the "spatial relationship of the entire region" [42-45]. In this study, Moran's I indices, which are frequently used in the literature, are used.

LISA, one of the spatial statistical analysis methods, was developed with an index determined by Moran in 1948 [46]. This study was extended by Anselin in 1995 [47]. It is used to examine the relationship between neighboring regions. A weight matrix is created depending on the geographical or political proximity of the neighbors. $W=$ $\left(w_{i j}: i, j=1, \ldots, n\right)$ is the $n \times n$ positive matrix as Eq. (2) [47]

$\left[\begin{array}{cccc}w_{11} & w_{12} & \cdots & w_{1 n} \\ w_{21} & w_{22} & \cdots & w_{2 n} \\ \vdots & \vdots & \ddots & \vdots \\ w_{n 1} & w_{n 2} & \cdots & w_{n n}\end{array}\right]$

The weight matrix, which is used to determine the neighborhood, can be defined as; if $i$ and $j$ "neighbors", then $W i j=1$, else $W i j=0$ [48]. The spatial autocorrelation value for each region is calculated with LISA. The GeoDa program is frequently used for the creation of maps and for the calculation of Local Moran's I [47].

The local Moran's I (LISA) used to determine local spatial autocorrelation is as Eqs. (3-5).

$I_{i}=\frac{Z_{i}}{k_{2}} \sum_{j} w_{i j} Z_{i}$

$k_{2}=\frac{\sum_{i} z_{i}^{2}}{N}$

$I=\sum_{i} \frac{I_{i}}{N}$

where, $I_{i}$ is the local spatial autocorrelation; $N$, number of observations; $Z_{i}$ is the deviation from the average. In other words, Moran calculates autocorrelation by looking at the correlation between the variable of interest and the spatial average of that variable. Spatial average of a variable is calculated by taking the average of that variable value in the neighbors. The results are described in four categories; high-high, low-low, high-low and low-high. For example, a low-high relation indicates that once the AQI in province $\mathrm{A}$ is low, the average AQI of the neighboring provinces of province $A$ is high. If there is also province $B$ which shows similar pattern around province $\mathrm{A}$, than province $\mathrm{A}$ and $\mathrm{B}$ are grouped. This indicates that these two provinces are under the influence of same regional source or process. 
Global spatial autocorrelation for Global Moran's I is calculated as Eqs. (6-7):

$I=\frac{n}{S_{0}} \frac{\sum_{i=1}^{n} \sum_{j=1}^{n} w_{i j}\left(x_{i}-\bar{x}\right)\left(x_{j}-\bar{x}\right)}{\sum_{i=1}^{n}\left(x_{i}-\bar{x}\right)^{2}}$

$S_{0}=\sum_{i=1}^{n} \sum_{j=1}^{n} w_{i j}$

where, $n$ is the number of cities; $x_{i}$ and $x_{i}$ is the AQI of a spatial location $i, j$ [49]. Global Moran indicies take values between -1 and +1 .

\subsection{Spatial Models}

In many similar scientific studies, the standard approach was started by developing the non-spatial linear regression model and then, by developing the model by examining the spatial interaction effects of the model [5052]. Linear regression models are often estimated by Ordinary Least Square (OLS). Spatial regression models, on the other hand, are assumed to be in correlation between each other, as opposed to traditional regression analysis [35].

In this study, it was started with the idea that neighboring provinces may have affected AQI values. It was studied with the idea that independent variables may also be affected by the neighborhood between provinces. SLM and SEM models were used to determine these interactions [53-54]). SEM model:

$Y=\alpha l_{n}+X \beta+\lambda W u+\varepsilon$

$\varepsilon \sim N\left(0, \sigma^{2} I_{n}\right)$

where $Y$ denotes an $N \times 1$ vector the dependent variable for every unit in the sample $(i=1, \ldots, N) ; l_{N}$ is an $N \times 1$ vector of ones associated with the constant term parameter $\alpha ; X$ denotes an $N \times K$ matrix of exogenous explanatory variables; $\beta$ is a $K \times 1$ vector of parameters; $\lambda$ is the spatial autocorrelation parameter; W denotes an $N \times N$ spatial weight matrix; $\mathrm{u}$ is an $N \times 1$ vector of residual and and $\varepsilon$ is a vector of normally distributed errors.

SLM model:

$Y=\alpha l_{n}+X \beta+\rho W Y+\varepsilon$

$\varepsilon \sim N\left(0, \sigma^{2} I_{n}\right)$

where $\rho$ is the auto-regressive parameter [53-54],[10].

In this study, parameter estimates were obtained by ordinary least squares Estimation (OLS) method. All spatial regression modeling was conducted using Anselin's Geoda Space and Geoda software. We used ArcGIS 10.6 and Geoda to generate maps.

\section{Results and Discussion}

\subsection{Spatial Relationship Results for AQI}

In the literature, there are studies that take the AQI as the dependent variable (i.e. the variable described). In this study, we examined which independent variables we can explain the AQI. We also examined whether there is a spatial relationship in the global and local sense. Based on this relationship, we wanted to suggest a model. Both cluster maps and Moran I index calculations proved that the air quality index and other variables show a spatial distribution. The spatial distribution maps for AQI (Figure 2) showed that all the variables determined were affected positively from neighboring provinces (i.e., the increase in the value of one province also increased in the neighboring province) Moran's I value was obtained as 0.279 .

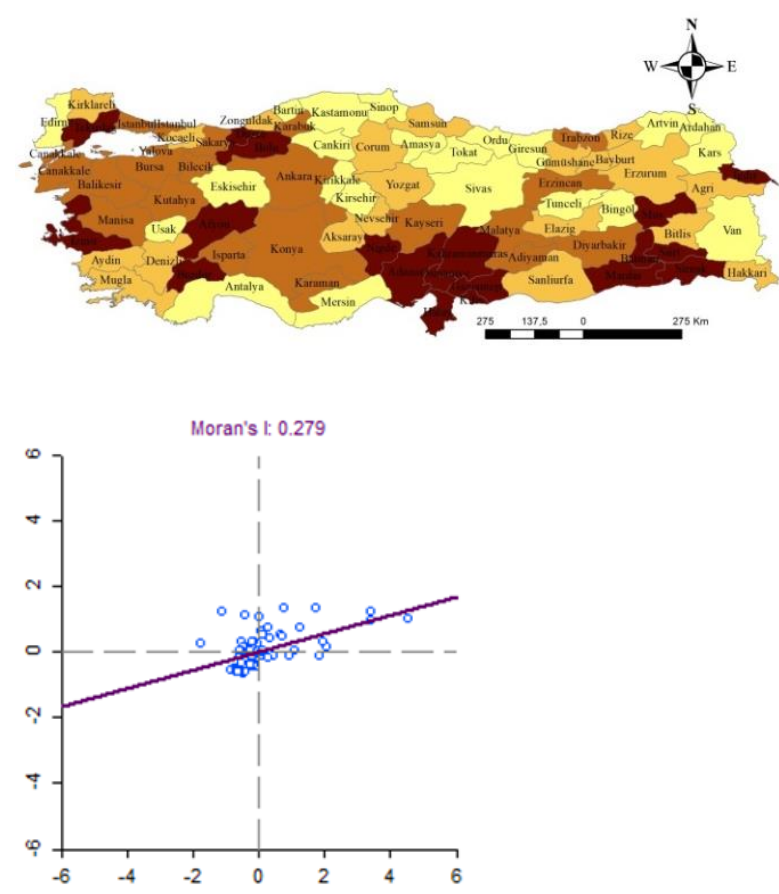

Figure 2. Spatial distribution of the AQI and Moran's I value for 2015 years.

In this study, spatial regression models were applied instead of the traditional regression model to investigate the relationship between the air quality index and meteorological and anthropogenic factors. The results of the variables showed that the independent variables determined for the spatial regression model are in a strong spatial relationship. These results show that AQI values are positively affected by neighboring provinces. These results are consistent with study in China [55]. 


\subsection{Spatial Model Selection for AQI}

For the error estimation of AQI, the ordinary least squares (OLS) method and classical regression model followed by the Spatial Error Model (SEM) was studied using MATLAB and Stata14 programs.

While choosing the spatial model, it was examined whether the spatial effect was caused by the error term or by delay. Yalcin et al. [25] worked with the data of the year 2014 and found out that the coefficient of determination (R2) of the OLS model was 0.2102, while R2 for the SEM was 0.2478. This result showed that a SEM is a better model than the OLS model. Also, the value of $\rho$ in the model is 0.680 which is statistically significant.

Similarly, spatial analysis was made for data of the year 2015. It was concluded that the spatial effect occurred without spatial delay (probability values $0.070<0.079$ ). For this reason, SLM model has been proposed. For the year 2015, the model's R2 with OLS was 0.238 , whereas for SLM, the R2 was 0.290 . This result showed that a SLM was a better model than the OLS regression model. At the same time, the $\rho$ value in the model was 0.320 and was statistically significant (Table 4). This value indicates that a $1 \%$ increase in the AQI value in one province causes a $3.2 \%$ increase in the AQI value in the neighboring provinces.

Results indicates that both OLS and SLM models showed statistically significant negative correlation with wind speed. It is well known that as the wind speed increases fresh air dilutes the polluted air in the cities and hence, AQI decreases. The GDP, on the other hand, showed statistically significant $(\mathrm{p}<0.05)$ positive correlation. This fact indicated that, although the coefficients were low, as the GDP of the cities increases, people tend to release more pollution to air. Finally, number of people per car data had a positive correlation in SLM model. The other parameters such as humidity, altitude, total precipitation, total population also showed correlation but their significance were between 0.10 and 0.05 .

Table 4. OLS and SLM Model Coefficients for 2015.

\begin{tabular}{|c|c|c|c|c|c|}
\hline Variables & OLS & SLM & Spatial Relationship & Value & Probability value \\
\hline CONSTANT & $1.8997 * *$ & $2.365 * *$ & & & \\
\hline Wind speed & $-18.3913 * *$ & $-16.5763 * *$ & Moran's I(error) & 2.9484 & 0.003 \\
\hline Average Actual Pressure & $-0.5737 *$ & -0.4613 & Log-Likelihood & -471.384 & \\
\hline Average Humidity & $5.4329 *$ & $4.8364 *$ & LM (lag) & 3.2805 & 0.070 \\
\hline Google Altitude(M) & $0.05644 *$ & $0.0525 *$ & Robust LM (lag) & 0.2239 & 0.636 \\
\hline Average Sunshine Duration & 9.2518 & 10.1284 & LM (error) & 3.0793 & 0.079 \\
\hline Total Precipitation & $-0.009303^{*}$ & $-0.011^{*}$ & Robust LM (error) & 0.0227 & 0.636 \\
\hline Average Temperature & 20.1848 & 17.5375 & LM (SARMA) & 3.3032 & 0.191 \\
\hline Number of people per car & 0.1878 & $0.056^{* *}$ & & & \\
\hline GDP & $0.002 * * *$ & $0.0003 * *$ & & & \\
\hline Per capita GDP & $-0.00002 *$ & -0.003 & & & \\
\hline Total Population & $-0.731 *$ & $-0.7338^{*}$ & & & \\
\hline Population Density & $0.2760 *$ & 0.2338 & & & \\
\hline $\mathrm{W}=\rho$ & & $\mathbf{0 . 3 2 0} * * *$ & & & \\
\hline AIC & 980.664 & & & & \\
\hline SIC & 1021.370 & & & & \\
\hline R-squared & 0.238 & & & & \\
\hline Pseudo R-squared & & 0.290 & & & \\
\hline
\end{tabular}

\subsection{LISA Map Results}

For local spatial autocorrelation a result, local Moran's I indices of each city's AQI were calculated and were showed in Figure 3 and Figure 4 for the years 2014 and 2015, respectively.

The local Moran's I index results are between 0 and 1. There is said to be a correlation when the index value is greater than 0 . The correlation is stronger as the index value approaches to 1. The local Moran's I index for AQI values were calculated as 0.239 and 0.300 for the years 2014 and 2015, respectively. This result shows that according to AQI values more cities were correlated by each other in 2015.

LISA maps the year 2014 showed that 7 cities in two regions were categorized as high-high, 5 cities in two regions classified as low-low. In addition, the neighboring relationship was not statistically significant for 69 
provinces. High-high relations were observed in Zonguldak, Bolu and Düzce provinces on Black Sea region and Mardin, Diyarbakır, Batman and Siirt provinces in Southeastern Anatolia. AQI values for the year 2014 of Zonguldak, Bolu and Düzce provinces, showed statistically significant correlation $(\mathrm{p}<0.01)$ with Pearson correlation coefficient varying between 0.602 (Zonguldak-Bolu) and 0.735 (Zonguldak-Düzce). The AQI of these provinces were statistically higher than the surrounding provinces. There are no strong natural source affecting this region. Therefore, anthropogenic emissions, especially coal combustion for household heating, seems to be the major source of pollution. Similar meteorological activity in the area could have a negative effect on accumulation of air pollutants in the atmosphere resulting in higher AQI. In the Southeastern Anatolia region, AQI for the year 2014 of the four provinces (Mardin, Diyarbakır, Batman and Siirt) also showed statistically significant correlation $(\mathrm{p}<0.01)$ with Pearson correlation coefficient varying between 0.330 (Batman-Mardin) and 0.728 (Diyarbakır-Mardin). Winter season household heating in the area is expected to be the major local source. However, there is a very strong natural source in the region: desert dust transport from Arabian Peninsula [56]. The dust transport from Arabian Peninsula seems to increase AQI values in the region.

For the both of the low-low zones observed in 2014, the AQI values were observed lower than the surrounding provinces. The reason of low AQI from the surrounding provinces could be due to lower pollutant emissions than the surrounding provinces or have a different meteorological condition that increases the air quality of the regions. In general, we do not expect to see lower emissions form the surrounding provinces under same meteorological activities, but location of the downtown area might have an effect on such observation.

LISA maps of AQI values for 2015 showed us that. Eight provinces in two regions were categorized as highhigh, eight provinces were grouped as low-low in one region and two provinces were clustered as low-high. In addition, the neighboring relationship was not statistically significant for 63 cities. The low-low zone for the year 2015 in the Central Black Sea coast and composed of Kırıkkale, Çorum, Kastamonu, Sinop Samsun, Ordu, Tokat and Amasya provinces. On the east of the low-low region, there was a low-high region consist of Bartın and Zonguldak provinces. AQI values for the year 2015 of these low-low and low-high classified nine provinces, showed statistically significant correlation $(\mathrm{p}<0.01)$ with Pearson correlation coefficient varying between 0.265 (Kırıkkale-Sinop) and 0.845 (Çorum-Tokat). The results indicate that the meteorological conditions on the Central Black Sea coast together with some central Anatolia region decreases the AQI of the area. On the south of low-high region, there was a high-high cluster. This cluster was composed of Sakarya, Düzce and Bolu provinces. Daily AQI values for the year 2015 of these three provinces showed statistically significant correlation $(p<0.01)$ with Pearson correlation coefficient varying between 0.320 (Sakarya-Bolu) and 0.749 (Düzce-Bolu). These three cities AQI values also showed statistically significant correlation with low-low and low-high provinces located on the Black Sea coast and Central Anatolia region $(p<0.05)$. This indicates that AQI show similar pattern for this group of provinces. As indicated previously, there is not any regional natural source in the region. The only regional parameter is the meteorological events (precipitation and wind speed). These parameters could vary from province to province due to the topography of the downtown area. Therefore, this high-high relation could be a result of local anthropogenic emissions and similar negative effect of meteorological events. The second high-high cluster was on the south Anatolia and composed of Niğde, Adana, Kilis and Osmaniye and Antakya provinces. Daily AQI values for the year 2015 of these three provinces showed statistically significant correlation $(\mathrm{p}<0.01)$ with Pearson correlation coefficient varying between 0.439 (NiğdeAntakya) and 0.845 (Antakya-Osmaniye). In Adana, agriculture and agriculture related industry is dominant. In between Adana, Antakya and Osmaniye provinces, İskenderun Heavy Industry Zone is located. However, in the downtown area of the other provinces, there is not any important industrial area. Therefore, this high-high trend in the region could not be due to local or regional anthropogenic emissions. As indicated earlier, the South Eastern part of Anatolia region is under influence of desert dust transport from Arabian Peninsula. Also, studies conducted in this region showed that desert dust transport from Northern Africa increases the particulate matter concentrations in the region [57-58]. Therefore, the regional dust transport has a negative effect on AQI of these cities. 


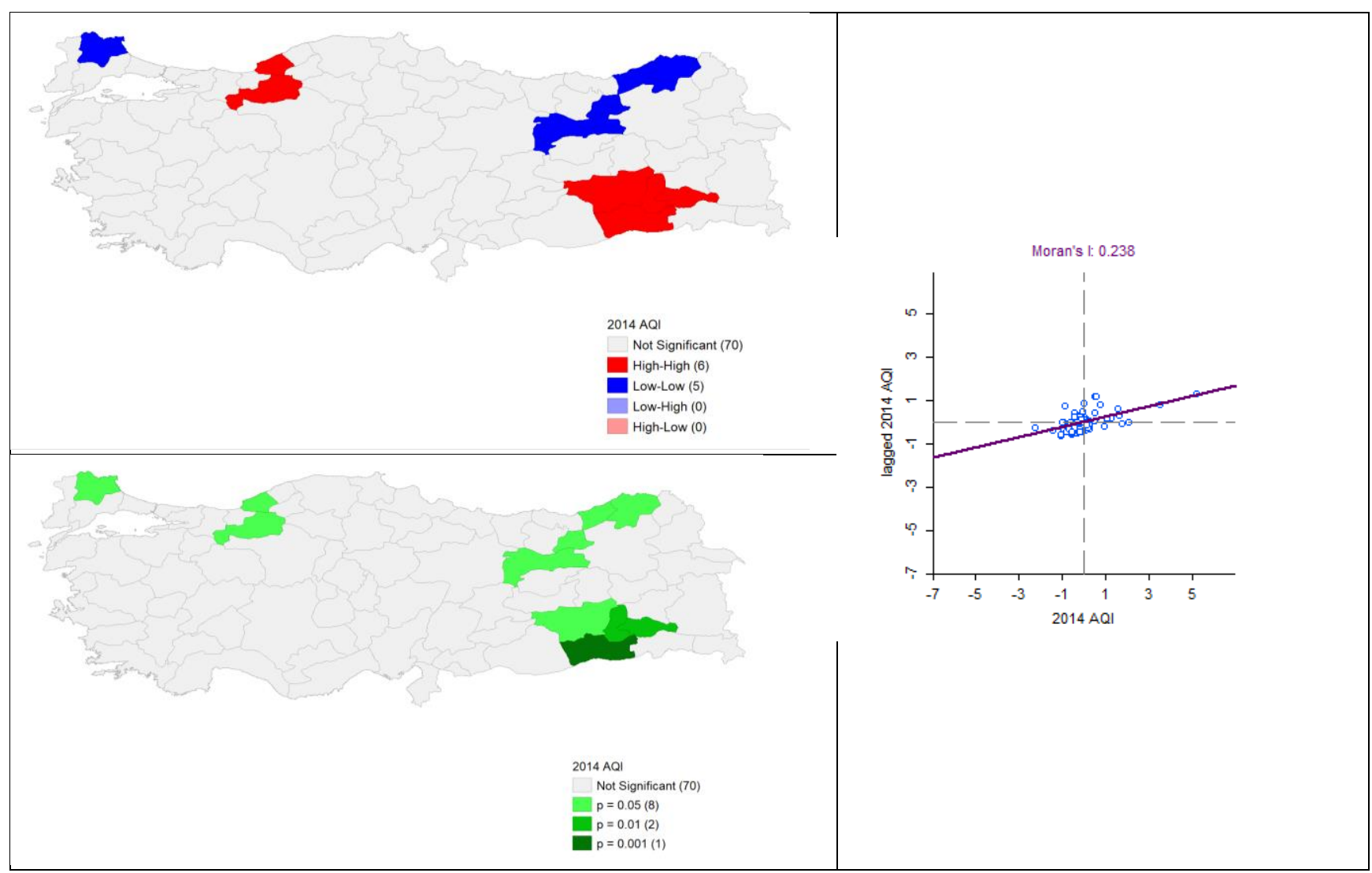

Figure 3. AQI Local Moran's I Graph and LISA Map for 2014.

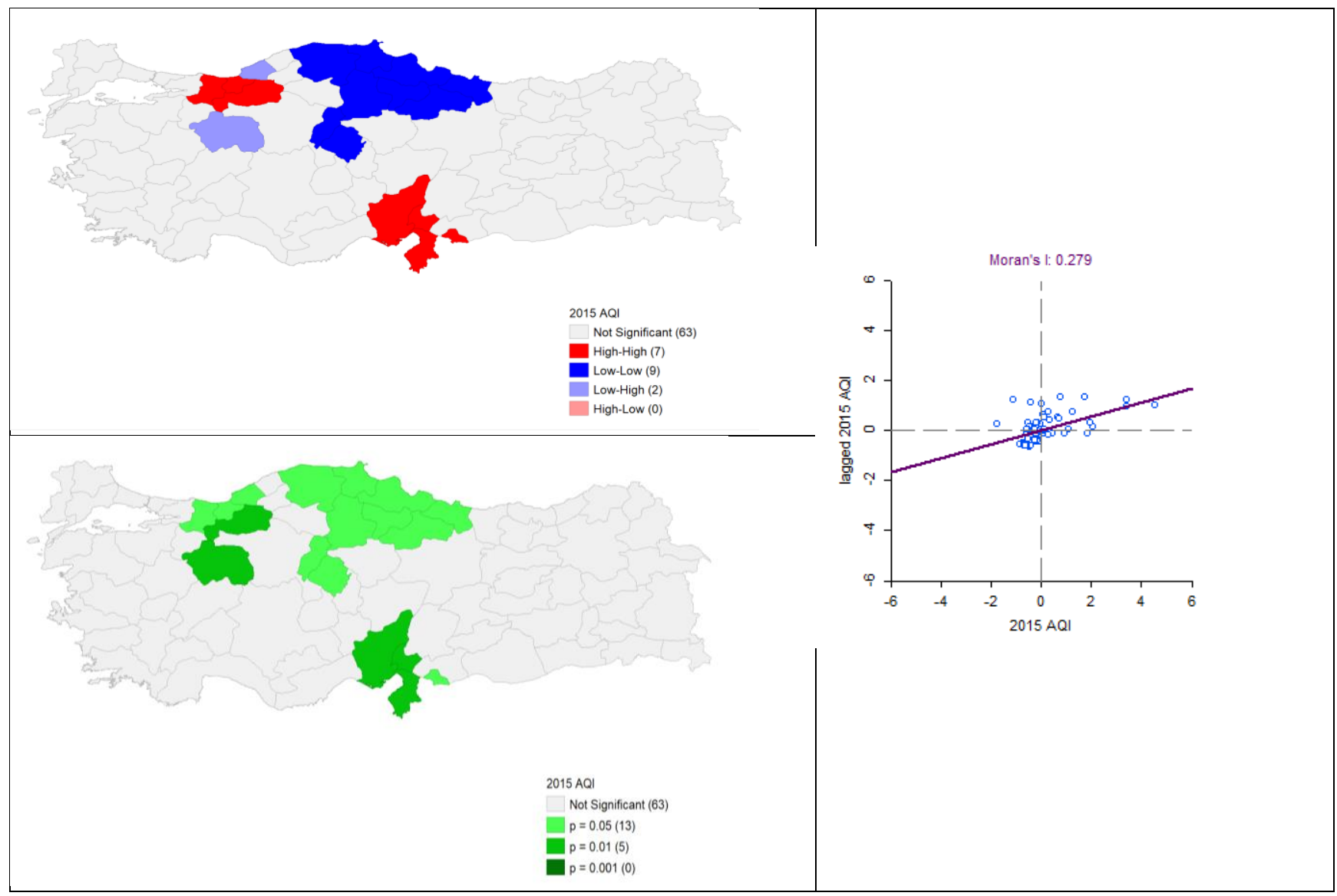

Figure 4. AQI Local Moran's I Graph and LISA Map for 2015. 


\subsection{Comparison of the AQI values of the years 2014 and 2015}

Before the comparison of the averages of 2014 and 2015 AQI values of provinces basis, normality test was conducted. The average values of the provinces were analyzed with the Kolmogorov-Smirnov Test and ShapiroWilk test provided by the normality assumption (Table 5). Accordingly, it was determined that the data is normally distributed for both years.

Table 5. Tests of Normality of Annual Average AQI of Cities for the years 2014 and 2015.

\begin{tabular}{|l|l|l|l|l|l|l|}
\hline \multicolumn{7}{|l|}{ Tests of Normality } \\
\hline & Kolmogorov-Smirnov & \multicolumn{3}{l|}{ Shapiro-Wilk } \\
\cline { 2 - 7 } & Statistic & df & Sig. & Statistic & df & Sig. \\
\hline $\begin{array}{l}\text { Average } \\
2014\end{array}$ & 0.075 & 80 & $0.200^{*}$ & 0.977 & 80 & 0.170 \\
\hline $\begin{array}{l}\text { Average } \\
2015\end{array}$ & 0.077 & 80 & $0.200^{*}$ & 0.981 & 80 & 0.275 \\
\hline *. This is a lower bound of the true significance. \\
\hline
\end{tabular}

The mean of the cities average AQI values were not statistically different than each other with $95 \%$ confidence interval. This expected since most of the time, $\mathrm{PM}_{10}$ values are lower than the $100 \mu \mathrm{g} / \mathrm{m}^{3}$ and below this level, AQI and $\mathrm{PM}_{10}$ levels show correlation with a line $y=x$. The correlation between average AQI of the years 2014 and 2015 are shown in Figure 5.

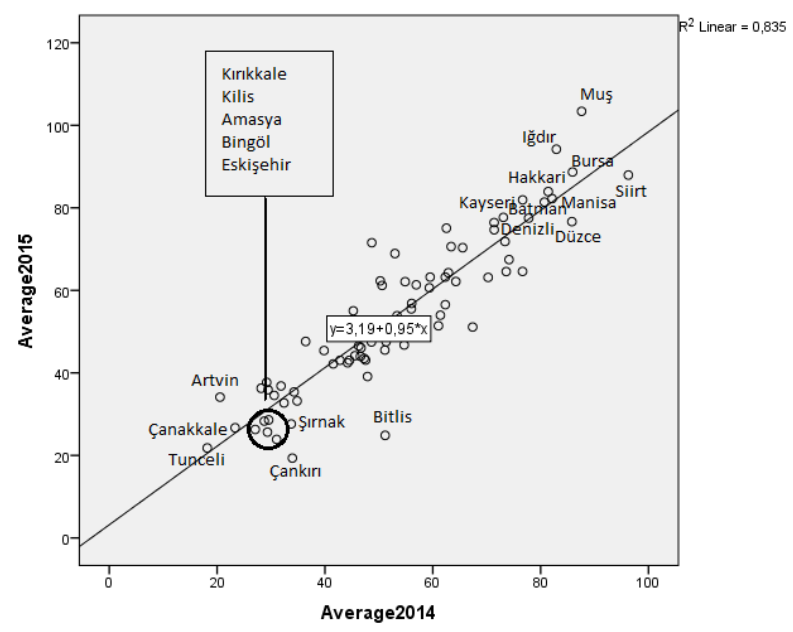

Figure 5. Correlation of average AQI of the provinces in Turkey for the years 2014 and 2015.

Only Muş for the year 2015 exceeded average AQI level of 100. This indicates that the air quality in Muş province was unhealthy for sensitive groups for the year 2015. In both years, 39 provinces had an average AQI less than 50 (Good) and rest of provinces had an average AQI between 51 and 100 (Moderate).
Table 6. Pearson Correlation Result of Annual Average AQI of Cities for the years 2014 and 2015.

\begin{tabular}{|c|c|c|c|}
\hline \multicolumn{4}{|c|}{ Correlations } \\
\hline & & Average2014 & Average2015 \\
\hline \multirow[t]{2}{*}{$\begin{array}{l}\text { Average } \\
2014\end{array}$} & $\begin{array}{l}\text { Pearson } \\
\text { Correlation }\end{array}$ & 1 & $0.914^{* *}$ \\
\hline & $\begin{array}{l}\text { Sig. } \\
\text { (2-tailed) }\end{array}$ & & 0.000 \\
\hline
\end{tabular}

Since the data is normally distributed, the Pearson Correlation coefficient is examined and the coefficient was found to be 0.914 , which is statistically significant in the $99 \%$ confidence interval. This result shows us that there is a strong relationship between the averages of 2014 and 2015 AQI values (Table 6).

The AQI values of the provinces for the years 2014 and 2015 are given in Figure 6 and Figure 7, respectively. The average AQI values of all cities were $53.1 \pm 18.2$ and $53.7 \pm 18.9$ for the years 2014 and 2015 , respectively. The highest average AQI was calculated as 103 for Mus for the year 2015. The lowest average AQI was calculated as 18 for Tunceli for the year 2014 .

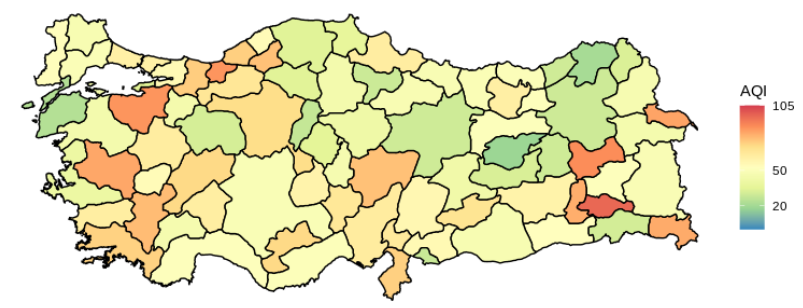

Figure 6. Average AQI values of the provinces in Turkey for the year 2014.

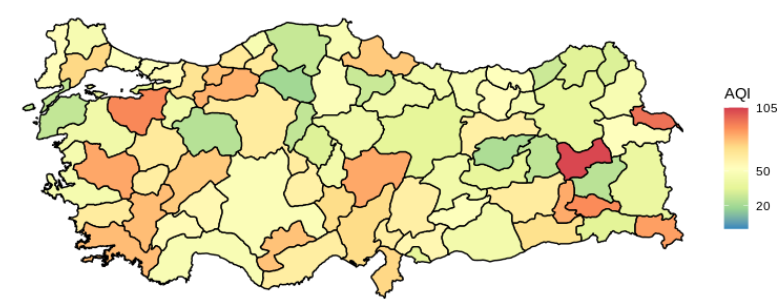

Figure 7. Average AQI values of the provinces in Turkey for the year 2015 .

It was determined that 9 out of 10 provinces with the highest AQI values were the same in both years. These nine provinces were Muş, Iğdır, Bursa, Siirt, Hakkâri, Manisa, Kayseri, Batman, Muğla and Denizli.

Muş, Iğdır, Siirt, Hakkâri and Batman provinces were located on the East Anatolia. There were almost no industrial activities on downtown area of the provinces. The main reason of the high AQI on these cities was 
probably due to household heating and traffic emissions. Bursa and Kayseri were located on Marmara region and central Anatolia, respectively and Manisa and Denizli were on western Anatolia. These four cities host industrial production. Therefore, aside from household heating and traffic, industrial emissions could also contribute to high AQI. Muğla, on the other hand, was located on the Aegean Sea. Downtown Muğla was located $15 \mathrm{~km}$ from the sea and there were almost no industrial activities in downtown area of the province. Hence, household heating together with traffic emissions were the main sources of pollution in Muğla.

Six of the ten lowest AQI cities of the years 2014 and 2015 were the same. These were Tunceli, Çanakkale, Kırıkkale, Bingöl, Amasya and Rize. These six cities are located on different parts of the Anatolia (Tunceli and Bingöl are in Eastern Anatolia, Çanakkale is between Marmara and Aegean seas, Kirkkkale and Amasya are in central Anatolia and Rize is in Eastern Black Sea) is in and there were no important industrial settlements in the downtown areas of the cities.

\section{Conclusions}

Understanding the need for regional air quality is going to help us to recognize the driving forces underneath. This study brings a different perspective to reveal the effects of natural and anthropogenic factors that are thought to affect the air quality index, which helps to understand air pollution. Considering the distribution of air pollution, the focus is on spatial autocorrelation. In this context, we tried to estimate the parameters of natural and anthropogenic effects through spatial regression models. It has been observed that there is a spatial distribution map of AQI values and Global Moran's I value (0.279). This information shows us that the AQI values in one province are affected by the AQI values in the neighboring province. Priority OLS method was used for parameter estimation of 12 independent variables which are thought to have an effect on AQI value and R2 value is 0.223 . Spatial error and spatial lag models were created in this investigation with ESDA. It was concluded that the spatial effect resulted from spatial delay (probability values 0.070 $<0.079$ ). For the SLM model, R2 was obtained as 0.290 . The model obtained with SLM was determined to be a better model compared to the model obtained according to the OLS method. In the model, the value of $\rho$ expressing the presence of spatial effect was statistically significant and was found to be 0.320 . This value indicates that a $1 \%$ increase in the AQI value in one province causes a $3.2 \%$ increase in the AQI value in the neighboring provinces. While wind speed causes a decrease in AQI value, increase in GDP increases AQI.

The average AQI values for 2014 and 2015 were compared. The Pearson correlation coefficient of between the cites for the consecutive years was found to be 0.914 , a value very close to 1 . This result showed that the average AQI values of 2014 and 2015 are in a strong correlation relationship. In both years, just 39 provinces had average AQI value below 50; indicating most of the cities were not in the good air quality category.

In this study, though average air quality of the provinces did not change significantly from one year to other, responses of cities to meteorological factors and regional dust transport plays an important role to change air qualities of the regions. Desert dust transport seems to increase AQI index of cities located on the Southern Anatolia whereas, meteorological factors either decreases or increases AQI of regions located on the Black Sea coast.

\section{Conflict of Interests}

No conflict of interest was stated by the authors.

\section{Acknowledgements}

This study was supported by Akdeniz University the Scientific Research Projects Coordination Unit with Project No: FBA-2018-3410.

\section{Declaration of Ethical Standards}

The authors of this article declares that the materials and methods used in this study do not require ethical committee permission and legal-special permission.

\section{References}

[1] World Health Organization. (2006). WHO Air Quality Guidelines for Particulate Matter, Ozone, Nitrogen Dioxide and Sulfur Dioxide: Global Update 2005: Summary of Risk Assessment (No. WHO/SDE/PHE/OEH/06.02). World Health Organization.

[2] Avnery S., Mauzerall D., Liu J., Horowitz L., 2011. Global Crop Yield Reductions Due to Surface Ozone Exposure: 1. Year 2000 Crop Production Losses and Economic Damage. Atmospheric Environment, 45(13), pp. 2284-2296.

[3] Nzotungicimpaye C. M., Abiodun B. J., Steyn D. G., 2014. Tropospheric Ozone and its Regional Transport Over Cape Town. Atmospheric Environment, 87, pp. 228-238. 
[4] Dimitriou K., Kassomenos P., 2015. Three Year Study of Tropospheric Ozone with Back Trajectories at A Metropolitan and A Medium Scale Urban Area in Greece. Science of the Total Environment, 502, pp. 493-501.

[5] Cape J.N., Fowler D., Davison A., 2003. Ecological Effects of Sulfur Dioxide, Fluorides, and Minor Air Pollutants: Recent Trends and Research Needs. Environment International, 29(2), pp. 201-211.

[6] EPA, 2014. Air Quality Index: A Guide to Air Quality and Your Health. NC, USA.

[7] Lee E., Chan C.K., Paatero P., 1999. Application of Positive Matrix Factorization in Source Apportionment of Particulate Pollutants in Hong Kong. Atmospheric Environment, 33(19). pp. 32013212.

[8] Querol X., Alastuey A., Rodriguez S., Plana F., Ruiz C.R., Cots N., Massagué G., Puig O., 2001. PM 10 and $\mathrm{PM}_{2.5}$ Source Apportionment in the Barcelona Metropolitan Area, Catalonia, Spain. Atmospheric Environment, 35(36), pp. 6407-6419.

[9] Mansha M., Ghauri B., Rahman S. Amman A. 2012. Characterization and Source Apportionment of Ambient Air Particulate Matter (PM2.5) in Karachi. Science Of The Total Environment, 425, pp. 176-183.

[10] Liu H., Fang C., Zhang X., Wang Z., Bao C., Li F., 2017. The Effect of Natural and Anthropogenic Factors on Haze Pollution in Chinese Cities: A Spatial Econometrics Approach. Journal of Cleaner Prod., 165, pp. 323-333.

[11] Xu W., Tian Y., Liu Y., Zhao B., Liu Y., Zhang X. 2019. Understanding the Spatial-Temporal Patterns and Influential Factors on Air Quality Index: The Case of North China. International Journal of Environmental Research and Public Health, 16(16), pp. 2820.

[12] Gaga E. O., Döğeroğlu T., Özden Ö., Ari A., Yay O. D., Altuğ H., Van Doorn, W., 2012. Evaluation of Air Quality by Passive and Active Sampling in An Urban City in Turkey: Current Status and Spatial Analysis of Air Pollution Exposure. Environmental Science and Pollution Research, 19(8), pp. 3579-3596.

[13] Demir M., Dindaroğlu T., Yılmaz S., 2014. Effects of Forest Areas on air Quality; Aras Basin and its Environment. Journal of Environmental Health Science and Engineering, 12(1), pp. 60.

[14] Tecer L. H., Tagil S., 2014. Impact of Urbanization on Local Air Quality: Differences in Urban and Rural Areas of Balikesir, Turkey. CLEAN-Soil, Air, Water, 42(11), pp.1489-1499.
[15] Dursun S., Alqaysi N. H. H., 2016. Estimating Air Pollution Quality In Istanbul City Centre By Geographic Information System. International Journal Of Ecosystems And Ecology Science-IjeeS, 6(3), pp. 329-340.

[16] Kurnaz K., Cobanoglu G., 2017. Biomonitoring of Air Quality in Istanbul Metropolitan Territory with Epiphytic Lichen Physcia Adscendens (Fr.) Olivier. Fresen. Environ. Bull, 26, pp. 7296.

[17] Baykara M., Im U., Unal A., 2019. Evaluation of Impact of Residential Heating on Air Quality of Megacity Istanbul by CMAQ. Science of the Total Environment, 651, pp.1688-1697.

[18] Güçlü Y. S., Dabanlı İ., Şişman E., Şen, Z., 2019. Air Quality (AQ) Identification by Innovative Trend Diagram and AQ Index Combinations in Istanbul Megacity. Atmospheric Pollution Research, 10(1), pp. 88-96.

[19] Gokce H. B., Arığlu E., Copty N. K., Onay T. T., Gun B., 2020. Exterior Air Quality Monitoring for The Eurasia Tunnel in Istanbul, Turkey. Science of The Total Environment, 699, pp. 134312.

[20] Dagsuyu C., 2020. Process Capability and Risk Assessment for Air Quality: an Integrated Approach. Human and Ecological Risk Assessment: An International Journal, 26(2), pp. 394-405.

[21] Yalcin F., 2016, "Spatial Analysis of The Factors Affecting The Room Price Offered by The Hotels in Antalya City" (in Turkish), Unpublished Doctorate Thesis, Akdeniz University, Graduate School of Social Sciences, Antalya, Turkey.

[22] Yalcin F., Mert M., 2018. Determinación de Precios Hedónicos de Habitación de Hotel con Efecto Espacial en Antalya. Economía, Sociedad y territorio, 18(58), pp.697-734.

[23] Kowe P., Mutanga O., Odindi J., Dube T., 2019. Exploring the Spatial Patterns of Vegetation Fragmentation Using Local Spatial Autocorrelation Indices. Journal of Applied Remote Sensing, 13(2), pp. 1-14.

[24] Lutz S.U., 2019. The European Digital Single Market Strategy: Local Indicators of Spatial Association 2011-2016. Telecommunications Policy, 43(5), pp. 393-410.

[25] Yalcin F., Tepe A., Dogan G., Cizmeci N., 2019. Investigation of Air Quality Index by Spatial Data Analysis: a Case Study on Turkey. Proceedings Book of the 2nd Mediterranean, 23. 
[26] Sensoy S., Demircan M., Ulupinar Y., Balta I., 2008. Climate of Turkey. Turkish State Meteorological Service, 401.

[27] Yalcin F., Tepe A. M., Doğan G., Cizmeci N. 2019. Regression Analysis of The Effect of Meteorological Parameters on Air Quality in Three Neighboring Cities Located on The Mediterranean Coast of Turkey. In AIP Conference Proceedings, July, Vol. 2116, No. 1, p. 100015. AIP Publishing LLC.

[28] CSB. 2020. SIM Veri Bankasi. (Web page: https://sim.csb.gov.tr) (Date accessed: 01.04.2020).

[29] Snow J., 1855. On the Mode of Communication of Cholera (2nd ed.). London: John Churchill.

[30] Fang C., Liu H., Li G., Sun D., Miao Z., 2015. Estimating the Impact of Urbanization on Air Quality in China Using Spatial Regression Models. Sustainability, 7(11), pp. 15570-15592.

[31] Mahara G., Wang C., Yang K., Chen S., Guo J., Gao Q., Guo, X., 2016. The Association Between Environmental Factors and Scarlet Fever Incidence in Beijing Region: Using GIS and Spatial Regression Models. International Journal of Environmental Research and Public Health, 13(11), pp.1083.

[32] Guo Y., Tang Q., Gong D. Y., Zhang Z., 2017. Estimating Ground-Level PM2. 5 Concentrations in Beijing Using a Satellite-Based Geographically and Temporally Weighted Regression Model.Remote Sensing of Environment, 198, pp. 140-149.

[33] Li H., You S., Zhang H., Zheng W., Zheng X., Jia J., Zou L., 2017. Modelling of AQI Related to Building Space Heating Energy Demand Based on Big Data Analytics. Applied Energy, 203, pp. 57-71.

[34] Tobler W. R., 1970. A Computer Movie Simulating Urban Growth in The Detroit Region. Economic Geography, 46(sup1), pp. 234-240.

[35] Anselin L., 1988. Spatial Econometrics: Methods And Models, Kluwer Academic Publishers, Dordrecht.

[36] Cliff A. D., Ord J. K., Haggett P., Versey G. R., 1981.Spatial Diffusion: An Historical Geography of Epidemics in an island community (Vol. 14). CUP Archive.

[37] Moran P.A.P., 1950a. Notes on Continuous Stochastic Phenomena. Biometrika, 37, pp.17-23.

[38] Moran P.A.P., 1950b. A Test for The Serial Independence of Residuals. Biometrika, 37, pp. 178181.
[39] Geary R. C., 1954. The Contiguity Ratio and Statistical Mapping. The Incorporated Statistician, 5(3), pp. 115-146.

[40] Getis A., 2008. A History of The Concept of Spatial Autocorrelation: A Geographer's Perspective. Geographical Analysis, 40(3), pp. 297-309.

[41] Wheeler D.C., Tiefelsdorf M., 2005. Multicollinearity and Correlation Among Local Regression Coefficients in Geographically Weighted Regression. Journal of Geographical Systems 7, pp. 161-87.

[42] Ord J. K., Getis A., 1995. Local Spatial Autocorrelation Statistics: Distributional Issues and an Application.Geographical Analysis, 27(4), pp. 286-306

[43] Anselin L., Bera A. K., Florax R., Yoon M. J., 1996. Simple Diagnostic Tests for Spatial Dependence. Regional Science and Urban Economics, 26(1), pp. 77-104.

[44] Getis A., Ord J. K., 1996. Spatial Analysis and Modeling in A GIS Environment. A research Agenda for Geographic Information Science, pp.157-196.

[45] Boots B., Tiefelsdorf M., 2000. Global and Local Spatial Autocorrelation in Bounded Regular Tessellations. Journal of Geographical Systems, 2(4), pp. 319-348.

[46] Moran P.A.P., 1948. The Interpretation of Statistical Maps. Journal of the Royal Statistical Society B., 10, pp. 243-251

[47] Anselin L., 1995. Local Indicators of Spatial Association-LISA, Geographical Analysis, 27, pp. 93-115.

[48] Anselin L., Florax, R.J.G.M., Rey, S.J. (ed.). 2004. Advances in Spatial Econometrics, Methodology, Tools and Applications. Springer-Verlag Berlin Heidelberg, Berlin.

[49] Anselin L., Hudak S., 1992. Spatial Econometrics in Practice: A Review of Software Options. Regional Science and Urban Economics, 22(3), pp.509-536.

[50] Li X. X., Wang L. X., Zhang J., Liu Y. X., Zhang H., Jiang S. W., Zhou X. N., 2014. Exploration of Ecological Factors Related to The Spatial Heterogeneity of Tuberculosis Prevalence in PR China. Global Health Action, 7(1), pp.23620.

[51] Jung M. C., Park J., \& Kim S., 2019. Spatial Relationships Between Urban Structures and Air Pollution in Korea. Sustainability, 11(2), p. 476. 
[52] Wang M., Wang H., 2020. Spatial Distribution Patterns and Influencing Factors of PM 2.5 Pollution in the Yangtze River Delta: Empirical Analysis Based on a GWR Model. Asia-Pacific Journal of Atmospheric Sciences, pp.1-13.

[53] Anselin L., 2013. Spatial Econometrics: Methods and Models (Vol. 4). Springer Science \& Business Media.

[54] Elhorst J. P., 2010. Applied Spatial Econometrics: Raising the Bar. Spatial Economic Analysis, 5(1), pp. 9-28.

[55] Liu, H., Fang, C., Zhang, X., Wang, Z., Bao, C., Li F., 2017. The Effect of Natural and Anthropogenic Factors on Haze Pollution in Chinese Cities: A Spatial Econometrics Approach. Journal of Cleaner Prod., 165, pp. 323-333

[56] Ecer A., Sarikaya B., Tepe A. M., Doğan, G., 2017. Mardin Ili Hava Kalitesinin Degerlendirilmesi. Paper Presented at the 7. Ulusal Hava Kirliliği ve Kontrolü Sempozyumu, Antalya, Turkey.

[57] Tepe A. M., Doğan G., 2016. Comparison of Effect of Saharan Dust Transport to Cities Located on Black Sea and Mediterranean Coasts of Turkey. Paper Presented at the 1st International Black Sea Congress on Environmental Sciences, Giresun, Turkey.

[58] Tepe A. M., Doğan G., 2019. Türkiye'nin Güney Sahilinde Yer Alan Dört Sehrin Have Kalitelerinin Incelenmesi. Mühendislik Bilimleri ve Tasarım Dergisi, 7(3) , pp. 585-595. 